\title{
Proximate composition and GC-MS analysis of ethanol extract of Solanum spirale Roxb.
}

\author{
Temin Payum* \\ Department of Botany, Jawaharlal Nehru College, Pasighat, East Siang District, Arunachal Pradesh-791103, India
}

Received: August 07, 2020

Revised: November 26, 2020

Accepted: December 03, 2020

Published: December 14, 2020

*Corresponding Author:

Temin Payum

Email: teminpayum519@gmail.

com

\begin{abstract}
Solanum spirale Roxb. is abundantly grown in eastern Himalayan regions. The shoot is used as a vegetable as well as medicine to control high blood pressure. The present study was carried out to profile the phytochemical compositions, mineral contents and proximate composition of the Solanum spirale shoot. GC-MS was used for the identification of phytochemicals and methods described in standard protocols were used to study minerals and proximate composition. A total of 40 phytochemicals were recorded from the ethanol extract. Mineral contents of the sample $0.115(\mathrm{Fe})$, $0.07(\mathrm{Mn}), 0.015(\mathrm{Cu}), 0.040(\mathrm{Zn}), 2.25(\mathrm{Mg}), 3.08(\mathrm{Na})$ and $16.7(\mathrm{~K}) \mathrm{mg} / \mathrm{g}$ while proximate composition were $76.25 \pm 0.093 \%$ (moisture) $3.82 \pm 0.26 \%$ (Carbohydrate), $12.54 \pm 0.08 \%$ (Total ash), $0.39 \pm 0.98 \%$ (Crude protein), $6.12 \pm 1.07 \%$ (Crude fibre), $0.37 \pm 0.07 \%$ (Crude fat). (Z,Z)-6,9-Cis-3,4-epoxy-nonadecadiene occupied highest area percentage in TIC peak report with 24.55\%, followed by Pentadecanoic acid with 18.81 percent, with Pentadecane with 9.99\%, Hexadecanoicacid, Ethyl ester with 8.64\%, (2E)(7R,11R)-3,7,11,15-Tetramethylhexadec-2-en-1-ol with 7.75\%. Useful phytocompounds related to health problems including anticancer, anti-inflammatory, antioxidant, antitumor, cardioprotective, hypocholesterolemic, increase zinc bioavailability, inhibit uric acid formation, antibacterial, antiinflamatory, antioxidant etc. are major components and such findings advocate Solanum spirale as a nutraceutical herb.
\end{abstract}

KEYWORDS: Medicinal food plant, Phytochemicals, High Blood Pressure, Proximate composition, Minerals

\section{INTRODUCTION}

Food and medicine represent a continuum rather than artificial categories; Overlapping nature of traditional food system and medicine lead to the investigation of phytochemicals that explains the food culture and health outcomes [1]. Any of the edible wild plants that are included in local food baskets have both therapeutic and dietary functions and such medicinal foods have been part of Eastern Medicinal theories since ancient times; In Traditional Chinese Medicine also the concept of food as medicine is based on the same basic theories and they are viceversa[2,3].North Eastern States of Eastern Himalayas is rich in biodiversity $[4,5]$, because of diverse ethnic groups, the region is equally rich in culture, traditional practices and customs. These people have rich knowledge on the utility of plant resources including herbal remedy; the region has many dimensions in food habits and flavour [6]. The shoot of Solanum spiraleis used as food as well as medicine by the tribal people in Eastern Himalayan region; as a medicine, it is use to lower down high blood pressure, loose motion and stomach pain, tender shoot is steam cooked as vegetable and berry is use as appetizer. The present study was selected to discourse the phytochemicals and proximate composition of Solanum spirale. This herb also grows commonly in North East India, China and Thailand. It blooms with spirally arranged white flower and berries are orange on ripe. Bark, leaf and berry tastes bitter. S. spirale has been reported to be an antioxidant potential herb [7]. The herb is also use as anti-tussive and anti-inflammatory agent historically [8]. Primary metabolites like proximate composition and minerals in a diet play vital role in promoting health growth and development; Minerals regulate cell function in more than one way; they are constituents of skeletal structures, they maintain colloidal state of the body matter and regulate acid base equilibrium, diffusion, and osmotic pressure and they are components or an activator of enzymes. Proximate composition of a diet provides energy, protein and other requirements of a body for healthy growth and development; secondary metabolites help in the remedy of various health problems and work as a nutraceutical food. With 
the above backdrops, the present research was taken up to study the proximate composition, phytoconstituents and minerals present in Solanum spirale shoot.

\section{MATERIAL AND METHODS}

\section{Sample Collection and Preparation}

Solanum spirale shoots were collected from Renging Village of Arunachal Pradesh, India. The herbarium was deposited in the Department of Botany, JN.College herbarium section with voucher number JNCTP/SOL/092019.The sample was washed thoroughly in distilled water and dried in shade till the weight did not changed further; and pulverized into powder, using a mechanical grinder. $500 \mathrm{~g}$ sample powder was subjected to Soxhlet apparatus in ethanol solvent, the slurry extract collected from rotary evaporator was used in the GC-MS analysis.

\section{Proximate and Minerals Studies}

For moisture study, fresh collected sample was used before drying. The following standard methods were followed in the proximate and minerals studies $[9,10,11]$. Ash content was determined in silica crucibles by incarnation in a muffle furnace at $550^{\circ} \mathrm{C}$ for 5 hrs. Crude lipid was extracted by continuous Soxhlet extraction with petroleum ether $\left(40-60^{\circ} \mathrm{C}\right)$. Crude fibre content was estimated by acid-base digestion with $1.25 \%$ $\mathrm{H}_{2} \mathrm{SO}_{4}$ and $1.25 \% \mathrm{NaOH}$ solution. Nitrogen was estimated by KjeldelMethod with steam distillation and titrated with standard 0.01 M HCL solution. Crude protein content was estimated by multiplying the sample per cent Nitrogen content by a factor 6.25 . ( $\%$ protein $=\%$ Nitrogen X 6.26). Carbohydrate was estimated by Anthrone Method with an ultravioletvisible (UV-Vis) spectrophotometer (Lamda-25, Perkin Elmer, Cambridge UK). Minerals were analysed from solution obtained when $1.0 \mathrm{~g}$ of the samples were digested with concentrated $10 \mathrm{ml}$ nitric acid and kept overnight and heated till fumes of $\mathrm{HNO}_{3}$ and allowed to cool and add $4 \mathrm{ml}$ concentrated Perchloric acid and heated again till clear solution is obtained and filtered into $100 \mathrm{ml} \mathrm{ml}$ standard flask and made to mark with distilled water and analysed in atomic absorption spectrophotometer (Buck scientific model 200A).

\section{Phytochemicals Studies}

To study phytochemical compositions, All the solvents used were purchased from Merck Company analytical grade. GC-MS: Gas-Chromatography Mass Specrometry (GC-MS) analyses of the each extract were carried out in Shimadzu GCMS-QP-2010 plus system. RTx-5 Sil MS column $(30 \mathrm{~m} \mathrm{X} 0.25 \mathrm{~mm}$ id X 0.25 film thickness) was used for the analysis. The operating conditions of the column were as follows: oven temperature program from $80^{\circ} \mathrm{C}$ to $210^{\circ} \mathrm{C}$ at $4^{\circ} \mathrm{C} / \mathrm{min}$ withhold time of $2 \mathrm{~min}$ and from $210^{\circ} \mathrm{C}$ to $300^{\circ} \mathrm{C}$ at $15^{\circ} \mathrm{C} / \mathrm{min}$ withhold time of $5 \mathrm{~min}$, and the final temperature was kept for $20 \mathrm{~min}$. The injector temperature was maintained at $270^{\circ} \mathrm{C}$, the volume of injected sample was $0.3 \mu \mathrm{l}$; pressure $85.4 \mathrm{kPa}$, total flow $76.8 \mathrm{~mL} / \mathrm{min}$, column flow $1.21 \mathrm{~mL} / \mathrm{min}$, linear velocity $40.5 \mathrm{~cm} / \mathrm{sec}$, purge flow $3.0 \mathrm{~mL} / \mathrm{min}$, split ratio: 60.0 ; ion source temperature $230^{\circ} \mathrm{C}$; scan mass range of $\mathrm{m} / \mathrm{z} 40-600$ and interface line temperature $280^{\circ} \mathrm{C}$. The identification of compounds was performed by comparing their mass spectra with data from NIST05 (National Institute of Standards and Technology, US) and WILEY 8.

\section{RESULTS}

A total of forty compounds (Figure 1) were identified (Table 1) from the ethanol extract and adequate mineral contents and proximate composition from Solanum spirale shoot was recorded; In the compound table, (Z,Z)-6,9-

Table 1: Chemical composition of ethanol extract of Solanumspirale

\begin{tabular}{|c|c|c|c|}
\hline Peak & RT & Area \% & Name of the compound \\
\hline 1 & 4.860 & 1.05 & 2-Pyrrolidinone, 1-methyl- \\
\hline 2 & 6.484 & 0.62 & $\begin{array}{l}\text { 2,3-Dihydro-3,5-dihydroxy-6-methyl-4h- } \\
\text { pyran-4-One }\end{array}$ \\
\hline 3 & 7.124 & 0.14 & 1-Tridecene \\
\hline 4 & 9.961 & 0.35 & 1-Tetradecene \\
\hline 5 & 10.091 & 0.38 & alpha.-Tetradecene \\
\hline 6 & 11.876 & 0.15 & $\begin{array}{l}\text { 2(4H)-Benzofuranone, 5,6,7,7a-tetrahydro- } \\
4,4,7 \text { a-trimethyl- }\end{array}$ \\
\hline 7 & 12.248 & 0.17 & Fumaric acid, ethyl 2-isopropylphenyl ester \\
\hline 8 & 12.461 & 0.52 & Phthalic acid \\
\hline 9 & 13.238 & 0.49 & Piperidine, 1-(1-cyclopenten-1-YL)- \\
\hline 10 & 13.447 & 0.33 & $\begin{array}{l}\text { 5-Hydroxymethyl-1,3,3-trimethyl-2-(3- } \\
\text { methyl-buta-1,3-dienyl)-cyclopentanol }\end{array}$ \\
\hline 11 & 13.578 & 0.22 & Santalol, cis,.alpha.- \\
\hline 12 & 13.647 & 0.26 & $\begin{array}{l}\text { Spirio-10-(2,11-dioxabicyclo[4.4.1]undeca- } \\
\text { 3,5-diene)-2'-(oxirane), 1,3,7,7-tetramethyl- }\end{array}$ \\
\hline 13 & 14.307 & 0.18 & $\begin{array}{l}\text { 6-(1-Hydroxyethyl)-2-iodo-4-oxa- } \\
\text { tricyclo[4.2.1.0(3,7)]nonan-5-one }\end{array}$ \\
\hline 14 & 14.597 & 0.11 & Benzyl Benzoate \\
\hline 15 & 14.637 & 0.22 & Calendin \\
\hline 16 & 15.223 & 0.82 & 2,6,10-Trimethyl,14-ethylene-14-pentadecne \\
\hline 17 & 15.479 & 0.31 & $\begin{array}{l}\text { Cyclopropanenonanoic acid, } \\
2-[(2-\text { butylcyclopropyl)methyl]-, methyl ester }\end{array}$ \\
\hline 18 & 15.674 & 0.48 & 3,7,11,15-Tetramethylhexadec-2-en-1-ol \\
\hline 19 & 16.543 & 18.81 & Pentadecanoic acid \\
\hline 20 & 16.714 & 0.16 & Ethyl 9-hexadecenoate \\
\hline 21 & 16.797 & 8.64 & Hexadecanoic acid, ethyl ester \\
\hline 22 & 17.746 & 0.17 & Heptadecanoic acid, ethyl ester \\
\hline 23 & 17.938 & 7.75 & $\begin{array}{l}(2 E)(7 R, 11 R)-3,7,11,15 \text {-Tetramethylhexadec- } \\
\text { 2-en-1-ol }\end{array}$ \\
\hline 24 & 18.240 & 24.55 & (Z,Z)-6,9-CIS-3,4-Epoxy-nonadecadiene \\
\hline 25 & 18.381 & 3.75 & Ethyl $(9 z, 12 z)-9,12$-octadecadienoate \\
\hline 26 & 18.435 & 9.99 & Dichloroacetic acid, tridec-2-ynyl ester \\
\hline 27 & 18.489 & 0.38 & 9-0ctadecenoic Acid (Z)- \\
\hline 28 & 18.669 & 4.56 & Octadecanoic acid, ethyl ester \\
\hline 29 & 18.961 & 0.44 & 1,E-11,Z-Octadecatriene \\
\hline 30 & 20.295 & 0.79 & 9-0ctadecenoic acid (z)- \\
\hline 31 & 20.465 & 0.96 & 1,3-Cyclopentanedione, 4-hydroxy-2-pentyl- \\
\hline 32 & 20.611 & 0.79 & Heptadecanoic acid, ethyl ester \\
\hline 33 & 23.457 & 0.51 & $\begin{array}{l}\text { Ethy } \\
\text { L margarate }\end{array}$ \\
\hline 34 & 25.158 & 0.22 & Octadecanoic acid, ethyl ester \\
\hline 35 & 26.357 & 0.22 & Heptadecanoate \\
\hline 36 & 26.567 & 2.07 & Squalene \\
\hline 37 & 29.844 & 3.39 & .gamma.-Tocopherol \\
\hline 38 & 31.249 & 2.13 & dl-.alpha.-Tocopherol \\
\hline 39 & 33.896 & 1.07 & Stigmasta-5,22-dien-3-ol \\
\hline 40 & 35.436 & $\begin{array}{l}1.89 \\
100\end{array}$ & Stigmast-5-en-3-ol, (3.beta.)- \\
\hline
\end{tabular}


Table 2: Biological activity of the identified compounds

Name of the compounds
2-Pyrrolidinone, 1-methyl-
2,3-DIHYDRO-3,5-DIHYDROXY-6-METHYL-4H-PYRAN-4-ONE
alpha.-Tetradecene
2(4H)-BENZOFURANONE, 5,6,7,7A-TETRAHYDR0-4,4,7A-TRIMETHYL-
Fumaric acid, ethyl 2-isopropylphenyl ester
PHTHALIC ACID
Santalol, cis-alpha.-
PENTADECANOIC ACID
HEXADECANOIC ACID, ETHYL ESTER
(2E)(7R,11R)-3,7,11,15-TETRAMETHYLHEXADEC-2-EN-1-OL
(Z,Z)-6,9-CIS-3,4-EPOXY-NONADECADIENE
ETHYL (9Z,12Z)-9,12-OCTADECADIENOATE
Dichloroacetic acid, tridec-2-ynyl ester
9-0CTADECENOIC ACID (Z)-
0CTADECANOIC ACID, ETHYL ESTER
9-0CTADECENOIC ACID (Z)-
1,3-Cyclopentanedione, 4-hydroxy-2-pentyl-
Heptadecanoic acid, ethyl ester
Ethy
L margarate
Squalene
gamma.-Tocopherol
dl-.alpha.-Tocopherol
Stigmasta-5,22-dien-3-0l
Stigmast-5-en-3-0l, (3.beta.)-

CIS-3,4-epoxy-nonadecadiene was recorded to occupy the highest area percentage with $24.55 \%$ followed by Pentadecanoicacid with $18.81 \%$; then Dichloroacetic acid, tridec-2-ynyl ester with $9.99 \%$, while Hexadecanoicacid, ethyl ester was in $8.64 \%$, Hexadecanoic acid, (2E) (7R,11R)-3,7,11,15-Tetramethylhexadec-2-en-1-olwith $7.75 \%$, and other phytocompounds are gamma-Tocopherol,2Pyrrolidinone, 1-methyl-, 2,3-dihydro-3,5-dihydroxy-6methyl-4h-pyran-4-one, 1-Tridecene, 1-Tetradecene, alpha.Tetradecene, 2(4H)-benzofuranone, 5,6,7,7A-tetrahydro4,4,7a-trimethyl-, Fumaric acid, ethyl 2-isopropylphenyl ester, Phthalicacid, piperidine, l-(1-cyclopenten-l-yl)-, Santalol, cis-alpha.-, 5-Hydroxymethyl-1,3,3-trimethyl2-(3-methyl-buta-1,3-dienyl)-cyclopentanol, Spirio-10(2,11-dioxabicyclo[4.4.1] undeca-3,5-diene)-2'-(oxirane), 1,3,7,7-tetramethyl-, Benzyl Benzoate, 6-(1-Hydroxyethyl)2-iodo-4-oxa-tricyclo[4.2.1.0 (3,7)] nonan-5-one, CALENDIN, 2,6,10-Trimethyl,14-Ethylene-14-Pentadecne, Cyclopropanenonanoic acid, 2-[(2-butylcyclopropyl) methyl]-, methyl ester, 3,7,11,15-tetramethylhexadec-2en-1-ol, ethyl 9-hexadecenoate, Heptadecanoicacid, ethyl ester, (2e) (7r,1 r r)-3,7,1 1,15-tetramethylhexadec-2-en-1-ol, ethyl (9z,12z)-9,12-octadecadienoate, 9-octadecenoic acid (z)-, Octadecanoicacid, ethyl ester, l,e-l1,z-octadecatriene, 9-octadecenoic acid (z)-, ethyl margarate, Heptadecanoicacid, ethyl ester, 1,3-cyclopentanedione, 4-hydroxy-2-pentyl-, octadecanoic acid, ethyl ester, Heptadecanoate. Mineral contents of the sample was recorded in $\mathrm{mg} / \mathrm{g}$ asFe $0.115, \mathrm{Mn}$ 0.07, Cu 0.015, Zn 0.040, Mg 2.25, Na 3.08 and K 16.7 and proximate composition was recorded as $76.25 \pm 0.093 \%$ (moisture), $3.82 \pm 0.26 \%$ (Carbohydrate), $12.54 \pm 0.08 \%$ (Total ash), $0.39 \pm 0.98 \%$ (Crude protein), $6.12 \pm 1.07 \%$ (Crude fibre), $0.37 \pm 0.07 \%$ (Crude fat).
Biological activity

Catechol-0-Methyl- transferase -inhibitor [12].

Methyl-guinidune-inhibitor [12].

5-alha-reductase inhibitor [12].

Antidote, anti HIV integrase, HIFl alpha inhibitor[12].

Smart drug, 11B-HSD inhibitor, 5 HETE inhibitor[12].

Inhibit uric acid formation [12].

5-alpha-reductase inhibitor [12].

Inhibit uric acid formation [12].

Inhibit uric acid formation [12].

Endocrinprotective [12].

Increase zinc bioability [12].

Increase zinc bioability [12].

Inhibit uric acid formation [12].

Acidifier [12].

Inhibit uric acid formation [12].

Inhibit uric acid formation [12].

17-beta-hydroxysteroid dehydrogenase-inhibitor [12].

Inhibit uric acid formation [12].

Anticancer, antioxidant [12].

Monooxygenase-inhibitor[12], antioxidant, antitumour[13].

Antioxidant, Tocopherol synergist, PPAR-Gamma-Antagonist [12].

Antioxidant,TNF-alpha inhibitor [12].

Antimicrobial [14].

Anti-diabetic; apart from its existing cholesterol lowering efficacy [15].

\section{DISCUSSION}

The Solanum spirale shoot contains useful primary as well as secondary metabolites. The ethanol extract of Solanum spirale shoot contain as many as twenty three useful phytocompounds (Table 2) in addition to proximate and minerals composition for healthy growth and development of body. (Z,Z)-6,9-cis-3,4-epoxy-nonadecadiene increase zinc bioavailability and availability of zinc boost immune system in body,PENTADECANOIC ACID stop uric acid formation and uric acid is one of the major problems with nonvegetarian food habit people, Pentadecane is antibacterial, anti-inflamatory, anticancer; Dichloroacetic acid, tridec-2ynyl ester and hexadecanoic acid, ethyl ester also inhibit uric acid formation;Hexadecanoic acid is hypocholesterolemic,and antioxidant, (2E) (7R,11R)-3,7,11,15-tetramethylhexadec2-en-l-ol is Endoanesthetic, endocrinprotective, gammaTocopherol is anticancer, anti-inflammatory, antioxidant, antitumor, cardioprotective, hypocholesterolemic, natriuretic. Presence of adequate amount of potassium, magnesium, iron, Carbohydrate, Crude protein and Crude fibre is important for a healthy diet. Minerals and Proximate compositions in a food is vital for the proper growth and development of a healthy body and secondary metabolites included in diet act as a nutraceuticals thus help in fighting various health problems. The findings of Keawsa-ard et. al., [16]: also support the results and finding present study in which the essential oil of Solanum spirale Roxb. unripe fruits is reported to exhibit anticancer activities against MCF-7 (breast cancer) and NCI-H187 (small cell lung cancer), antituberculosis activity against Mycobacterium tuberculosis H37Ra and also showed moderately antibacterial activity against Escherichia coli and Staphylococcus aureus. Likewise, Sukanya et. al., [17] also 


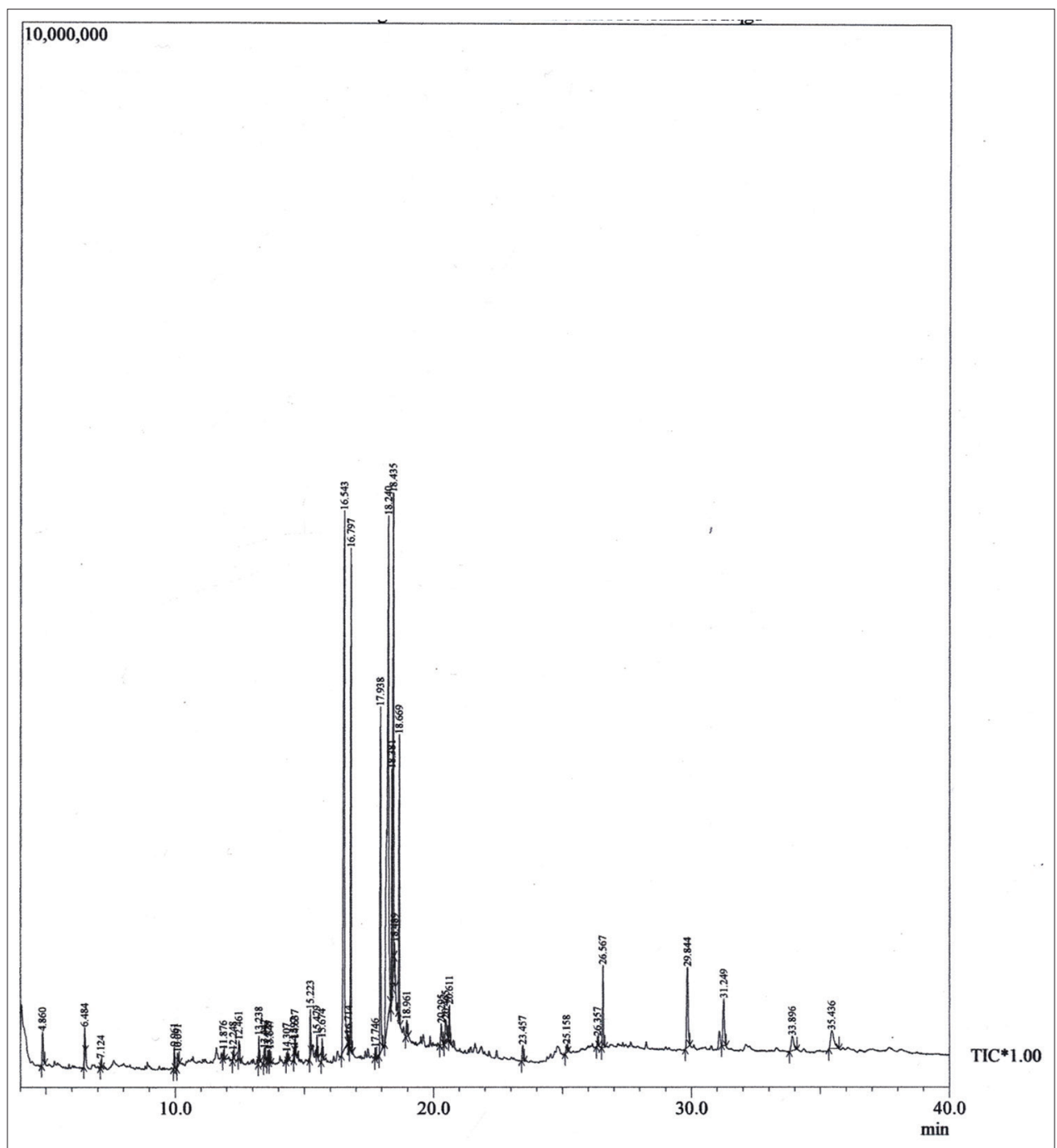

Figure 1: Chromatogram ofethanol extractSolanumspirale shoot.

reported the Solanum spirale leaf essential oil also reported to showed significant antibacterial activity against both Gramnegative Escherichia coli and Gram-positive Staphylococcus aureus and also showed significant cytotoxicity against KB (oral cancer), MCF-7 (breast cancer) and NCI-H187 (small cell lung cancer) and recently Payum et. al.,[18] have studied the Pharmacognostic characteristic of Solanum spirale shoot. In conclusion, Solanum spirale is a nutraceutical plant that provides energy, minerals including various useful phytocompounds. Presence of anti stroke and cardioprotective compounds validate the traditional knowledge and practices. The present study suggests the need of further studies on this nutraceutical plant.

\section{ACKNOWLEDGEMENT}

The author acknowledges Prof. A.K Das and Dr. R. Ramashankar for guiding, NEIST, Naharlagun and the Biotech Hub, JN College, Pasighat for Laboratory facility.

\section{REFERENCES}

1. Pieroni A,Price L. Eating and Healing: Traditional Food as Medicine: Food Products Press, London; 2006: 2-5.

2. Weng W and Cheng J. 1996. The eastern perspective of functional foods based on traditional Chinese Medicine. Nutrition Reviews. 1996; 54: S11-S16.

3. Chen, J. Regulatory control of functional food in China. Scandinavian Journal of Nutrition.2000; 44: 130-131.

4. Myers N. Threatened Biotas: "Hot Spots" in the Tropical Forests. The Environmentalists. 1988; Vol. 8(3):187-208.

5. Myers N, Mittermeier RA, Mittermeier CA, da Fonseca GAB, Kent J. Biodiversity hotspots for conservation priorities. Nature 2000; Vol.403:853-858.

6. Payum T, Das AK, Shankar R, Tamuly C, Hazarika M. Ethnobotany and antioxidant determination of Phoebe cooperiana fruit- A highly utilized wild fruit in Arunachal Pradesh, India. IIPSR. 2013; 4(8): 3196-3201.

7. Payum T, Das AK, Shankar R, Tamuly C, Hazarika M. Antioxidant Potential of Solanumspiraleshoot and Berry: A medicinal food plant used in Arunachal Pradesh. AJPTR. 2015; 5(4): 308-314.

8. Dan L, Yun-Li Z, Xu-Jie Q, Lu L. Spiralosides A-C, Three New C ${ }_{27}$ Steroidal Glycoalkaloids from the Fruits of Solanumspirale. Natural Products and Bioprospecting. 2016; 6(4): 225-231.

9. Iswaran V: A Laboratory Handbook for Agricultural Analysis. Today 
and tomorrow's Printers and Publishers, New Delhi; 1980.

10. Thimmaiah SR. Standard Methods of Biochemical Analysis.Kalyani Publishers, New Delhi; 1999.

11. Raghuramulu N, Nair K, Kalyanasundaram S. A Manual of Laboratory Techniques. National Institute of Nutrition.ICMR, Hyderabad; 2003.

12. 11. Dr. Dukes Phytochemical and Ethnobotanical data baseshttps:// phytochem.nal.usda.gov/phytochem/search/list. Last accessed on 05.08.2020.

13. AchikaJ, Ndukwe GI, Ayo R. Isolation, Characterization and Antimicrobial Activity of 3 $\beta$, 22E-Stigmasta-5, 22-dien-3-ol from the Aerial Part of Aeschynomeneuniflora E. Mey. British Journal of Pharmaceutical Research.2016; 11(5).

14. Sujatha S, AnandS, Sangeetha KN, Shilpa K, Lakshmi J, Balakrishnan A, Lakshmi, BS. Biological evaluation of (3B)-STIGMAST-5-EN-3-OL as potent anti-diabetic agent in regulating glucose transport using in vitro model.International Journal of Diabetes Mellitus. 2010; 2(2): 101-109.

15. Rajeswari G, Murugan M, Mohan VR. GC-MS analysis of bioactive components of Hugoniamystax L. (Linaceae). Research Journal of Pharmaceutical, Biological and Chemical Sciences. 2012; 3 (4): 301-308

16. Keawsa-ard $S$, LiawruangrathB, Liawruangrath $S$, Teerawutgulrag $A$, \& Pyne SG. (2016). Essential oil of solanum spirale fruits and its biological activities. Chiang Mai Journal of Science.2016; 43 (3): 546-554.

17. Keawsa-arda S, Liawruangratha $B$, Liawruangrathb S, Teerawutgulragb $A$ and Pynec SG. Chemical Constituents and Antioxidant and Biological Activities of the Essential Oil from Leaves of Solanum spirale. Natural Product Communications. 2012; Vol.7(7): 955-958. 